\title{
Screening of different exotic lines of tomato (Lycopersicon esculentum L.) under the agro climatic condition of Haripur
}

Izhar Khan ${ }^{1}$, Ijaz Hussain ${ }^{1}$, Mehboob Ahmed ${ }^{2}$, Shah Masaud Khan ${ }^{1 *}$ Ayub Khan ${ }^{1}$, Khalid Naveed ${ }^{1}$, Sardar Ali ${ }^{1}$, Izhar Hussain ${ }^{1}$ and Muhammad Sajid ${ }^{3}$

1. Department of Agricultural Sciences (Horticulture) University of Haripur-Pakistan

2. Hazara Agriculture Research Station, Abbottabad-Pakistan

3. Department of Agriculture, Hazara University, Mansehra-Pakistan

*Corresponding author's email: shahmasaudkhan@gmail.com

Citation

Izhar Khan, Ijaz Hussain, Mehboob Ahmed, Shah Masaud Khan, Ayub Khan, Khalid Naveed, Sardar Ali, Izhar Hussain and Muhammad Sajid. Screening of different exotic lines of tomato (Lycopersicon esculentum L.) under the agro climatic condition of Haripur. Pure and Applied Biology. Vol. 6, Issue 4, pp1251-1259.

http://dx.doi.org/10.19045/bspab.2017.600133

Received: 25/05/2017 Revised: 19/09/2017

Accepted: 22/09/2017

Online First: 26/09/2017

\section{Abstract}

Performance of fourteen different tomato (Lycopersicon esculentum L.) lines were evaluated at seed multiplication Farm Panian Haripur during 2013-2014. The study was laid out in randomized complete block design with three replications. Data was recorded on days to picking, days to flowering, fruits per plant ${ }^{-1}$, pericarp thickness, shelf-life, plant height, fruit weight, fruits cluster ${ }^{-1}$, flowers cluster ${ }^{-1}$, fruit length, fruit diameter and yield plant ${ }^{-1}$. Analysis of variances showed significant results for all the traits. Maximum values were observed for days to flowering (47.66), days to picking (116.66 days), flowers cluster ${ }^{-1}$ (6.72), fruits cluster ${ }^{-1}$ (4.88), fruit weight (105.10 g), plant height $(120 \mathrm{~cm})$, fruit diameter $(5.83 \mathrm{~cm})$, fruit length enclosure $(6.26)$, pericarp thickness enclosure $(0.94 \mathrm{~cm})$, shelf-life $\left(11.33\right.$ days), fruits plant ${ }^{-1}(32)$ and yield plant ${ }^{-1}$ (1247.55 grams). Whereas, minimum values were observed in days to flowering (24.66 days), days to picking (89.00), flowers cluster ${ }^{-1}$ (3.55), fruits cluster ${ }^{-1}$ (1.77), fruits plant $^{-1}$ (9.62), fruit weight (45.90 g), plant height $(73 \mathrm{~cm})$, fruit diameter $(4.09 \mathrm{~cm})$, fruit length enclosure $(4.63 \mathrm{~cm})$, pericarp thickness enclosure $(0.52$ $\mathrm{cm}$ ), The shelf-life (4 days), fruits plant $^{-1}$ (9.62), yield plant ${ }^{-1}$ (397.88 g). Among the studied lines, the LINE-105 was high yielding showing superiority in many contributing traits such as flowers cluster $^{-1}$, fruit plant ${ }^{-1}$ and yield and hence recommended for general cultivation. However the lines L108 and L109 exhibited better performance for majority of the traits, except yield, therefore these two lines could be used in further breeding programs.

Keywords: Comparison; Evaluation; Lines; Tomato; Yield

Introduction

Tomato is one of the important and most consumed vegetable throughout the world.
Tomato belongs to Solanaceae family.

Tomato is originated in Peru of South America and name of the crop came from 
the Aztec word "Tomato". It is a selfpollinated crop due to hermaphrodite flowers, introvert stigma, internal and synchronized anther dehiscence, and stigma receptivity [1]. Tomato is a true diploid with $2 n=24$ [2]. Plant is annual with herbaceous prostrate stem having determinate or indeterminate growth habit. In the determinate growth, terminal bud ends in a floral bud and further growth in arrested resulting in dwarf and bushy stature. In indeterminate growth, terminal bud is a leafy bud and terminal, lateral buds continue to grow, and there are less production of flowers and fruits [3]

There are around 7,500 tomato varieties grown in the world for various purposes. Heirloom tomatoes are becoming increasingly popular, particularly among home gardeners and organic producers, since they tend to produce more interesting and flavorful crops at the cost of disease resistance and productivity [4]. It was globally planted on an area of 4.75 million hectares with a total production of 159.3 million tons [5]. About 14\% of the world's vegetable production is accounted for tomato [6]. In Pakistan, during 2013-2014 tomato was grown on an area of 63.2 thousand hectares with production of 599.7 thousand tons. Tomato occupies a prime position in list of protective foods. It is a rich source of minerals like calcium $(48 \mathrm{mg} /$ $100 \mathrm{~g})$, sodium $(12.9 \mathrm{mg})$, trace elements, copper $(0.19 \mathrm{mg})$, vitamins like vitamin A (900 IU), vitamin C (27 mg), vitamin B complex (thiamine), essential amino acids and healthy organic acids like citric, formic and acetic acids [7].

Tomato production is affected by many types of stresses (biotic and abiotic stress) like diseases caused by fungi, bacteria, viruses and nematodes. There are many environmental stresses, which influence negatively on the growth and production of crops [8]. Moreover, there are various factors, which limited the production and growth of tomato such as high temperature, draught, salinity and its vulnerability to frequent insect and pest attacks. Diseases infestations are well known factors that decrease crop yields and expand production costs [9]. However, its yields in Pakistan are much lower comparatively from other countries. There are many more factors which are key roots for its low yield with lack of knowledge regarding methodology, the invasion of weed, absence of high production, insect and disease resilient cultivars, absence of timely nutrients etc. between the other significant elements, absence of high production cultivars is one of the significant constrains. Farmers are still using the old traditional methods for cultivation, but to increase tomato's yield and profits of farmer, high production of tomato cultivars should be introduced [10].

The availability of suitable high yielding varieties can also fill the gap in production. Therefore the present study was conducted with the following objective to screen different exotic tomato lines for yield and yield contributing parameters under Haripur conditions.

\section{Materials and methods}

The current research work "screening of different exotic lines of tomato (Lycopersicon esculentum L.) under the agro climatic condition of Haripur" was performed in 2013-14. Fourteen tomato lines were sown in Randomized Complete Block design (RCBD) with three replications. The row to row distance was $100 \mathrm{~cm}$ while plant to plant distance was kept $30 \mathrm{~cm}$, and each row was 2.5 meter long. The nursery seedbed was $60-120 \mathrm{~cm}$ wide and $20-25 \mathrm{~cm}$ high. Well decomposed farmyard manure and fine sand were added. Lines were drawn at $10-15 \mathrm{~cm}$ apart, over the length of the seedbed. The seeds were sown at thinly spaced on the lines and pressed gently. To 
ensure sufficient moisture for germination, the seedbeds were irrigated twice a day. Tomato seedlings of different lines were transplanted to experimental plots after the seedlings got transferable height (3 to leaves) and the data was recorded on the following parameters.

\section{- Days to flowering}

Days from date of sowing to $1^{\text {st }}$ flowering of randomly taken ten plants were recorded.

\section{- Days to picking}

The picking data was recorded on the first fruit pick from tomato plant from sowing date.

\section{- Number of flowers/cluster}

The data on number of flower/cluster of ten randomly selected plant was observed when maximum number of flower/cluster plant- ${ }^{1}$ release from tomato plant.

\section{- Number of fruits /cluster}

Average number of fruits per plant was recorded by counting the number of fruits of five randomly selected plants and their average was calculated.

\section{- Fruit diameter}

Fruit diameters were taken at midpoint of ten randomly selected fruit by using verniear caliper and average data were subjected for statistical analysis.

\section{- Fruit length}

The data for fruit length were randomly ten tomato fruits of randomly taken plants by measuring the distance from base to tip of the individual fruit and then their average was calculated.

\section{- Per fruit weight}

The fruit weight plant $^{-1}$ were recorded with the help of weight balance by weighing all the fruits present on ten randomly taken plants in each replication and average was calculated.

\section{- Shelf-life (days)s}

Shelf life begins with the harvest of fruit and lasts till the fruits start decay or deterioration of quality.

\section{- Plant height}

Height of ten randomly plant was measured with the help of meter ruler as the distance from ground level to the top shoot.

\section{- Pericarp thickness}

A high precision digital caliper was used to measure the pericarp thickness $(\mathrm{g} / \mathrm{cm} 2)$ of 3 discs taken at the equatorial region of 3 fruits per lines (10 fruits) selected from different blocks.

- Number of fruits/plant

The total numbers of fruits present at maturity was counted on randomly ten plants per replication.

\section{- Yield/plant}

By using an electronic weighing balance yield/plant weight in $\mathrm{kg}$ was recorded.

\section{Statistical analysis}

Averages were calculated for recorded data in each replication. These averages were subjected to statistical analysis for ANOVA and LSD according to [11]. The average of the two years data was taken and was analyzed by using statistical software Statistix 8.1.

\section{Results and discussion Plant Height (cm)}

The data pertaining to plant height of different tomato lines is presented in Table 1. Significant variation was found in plant height of different tomato lines. Highest plant height $(120.00 \mathrm{~cm})$ was observed in tomato LINE-105 followed significantly by LINE-103 $(119.00 \mathrm{~cm})$ least plant height $(73.00 \mathrm{~cm})$ was recorded in LINE-114 followed significantly by LINE-112 (80.67 $\mathrm{cm})$.

The significant variation in plant height can also be attributed to genetic potential of the access of tomato lines. More food assimilation might have encouraged the vegetative growth of the tomato line including LINE-105, LINE-102 and LINE103, which in turns produced taller plants as compared to the other lines and vice versa. These results match with the result of [12] who reported that the tomato line TMO 369 
produced the maximum plant $(116.60 \mathrm{~cm})$ and line TMO 260 of tomato give the minimum plants of $47.63 \mathrm{~cm}$.

\section{Days to Flowering}

The statistical analysis showed highly significant variation among all tomato lines. Data regarding days to flowering of different lines of tomato is given in Table I. The data showed to maximum days to flowering (47.66) were taken by LINE-105, significantly followed by LINE-103 with 45.33 days to flowering LINE-114 took the least days to flowering (24.67) significantly followed by LINE-112 (27.00) respectively. Genetic factor of the lines and the environmental conditions prevailing at the experimental site might have caused the earliness in flowering for LINE-112 and LINE-114.

As the LINE-105 had tallest plant (Table 1), so it can be argued that the tomato LINE105 had utilized food reserves in attaining vegetative growth which delayed flowering. Investigated four tomato varieties and reported significant differences [13]. Experimentation on six exotic cultivars of tomatoes was done at Battal Valley of District Mansehra, Pakistan and concluded that days to flowering ranged was between 37 to 47 days $[14,15]$.

\section{Days to pickings}

The data of days to picking showed highly significant differences. The data pertaining to the days to picking is shown table 1.The results showed to the maximum days to picking were taken by LINE-105, ( 116.6 days), significantly followed by LINE-103 ( 110.66 days). while least days to picking were found in LINE-112 and LINE-114 by taking 93.33 and 89.00 days to picking, respectively.

Experiment on 11 tomato cultivars at Northern Areas of Pakistan was conducted during 2003 and found out similar range for first picking between 82 to 96 days [16], while [17] studied various types of tomato at Peshawar and supported the present research work for. The reason might be due to differences in the genetic makeup, genetic potential of the genotypes and the environment where these genotypes were tested.

Table 1. Data on fourteen lines for plant height, days to flowering and days picking

\begin{tabular}{|c|c|c|c|}
\hline Tomato lines & Plant height $(\mathrm{cm})$ & Days to flowering & Days to picking \\
\hline LINE 101 & $99.00 \mathrm{~d}$ & $44.33 \mathrm{~b}$ & $105.00 \mathrm{c}$ \\
\hline LINE 102 & $109.33 \mathrm{~b}$ & $45.00 \mathrm{~b}$ & $105.33 \mathrm{c}$ \\
\hline LINE 103 & $119.00 \mathrm{a}$ & $45.33 \mathrm{~b}$ & $110.66 \mathrm{~b}$ \\
\hline LINE10 4 & $105.33 \mathrm{c}$ & $42.33 \mathrm{c}$ & $103.33 \mathrm{~cd}$ \\
\hline LINE 105 & $120.00 \mathrm{a}$ & $47.66 \mathrm{a}$ & $116.68 \mathrm{a}$ \\
\hline LINE 106 & $105.33 \mathrm{c}$ & $41.33 \mathrm{~cd}$ & $102.33 \mathrm{~d}$ \\
\hline LINE 107 & $98.33 \mathrm{~d}$ & $39.00 \mathrm{e}$ & $96.67 \mathrm{e}$ \\
\hline LINE 108 & $96.33 \mathrm{~d}$ & $40.00 \mathrm{de}$ & $96.33 \mathrm{e}$ \\
\hline LINE 109 & $91.33 \mathrm{e}$ & $35.33 \mathrm{f}$ & $95.33 \mathrm{e}-\mathrm{g}$ \\
\hline LINE 110 & $88.00 \mathrm{ef}$ & $34.66 \mathrm{f}$ & $95.67 \mathrm{ef}$ \\
\hline LINE 111 & $85.00 \mathrm{fg}$ & $34.00 \mathrm{f}$ & $95.33 \mathrm{e}-\mathrm{g}$ \\
\hline LINE 112 & $80.67 \mathrm{~g}$ & $27.00 \mathrm{~h}$ & $93.33 \mathrm{~g}$ \\
\hline LINE 113 & $83.67 \mathrm{gh}$ & $31.67 \mathrm{~g}$ & $94.00 \mathrm{fg}$ \\
\hline LINE 114 & $73.00 \mathrm{i}$ & $24.67 \mathrm{i}$ & $89.00 \mathrm{~h}$ \\
\hline LSD (5\%) & 3.8626 & 1.9098 & 2.2127 \\
\hline \multicolumn{4}{|c|}{$\begin{array}{ll}\text { Number of flowers cluster } & \text { LINE-105 and LINE-103 with } 6.67 \\
\text { All the lines showed significant difference } & \text { significantly followed by } 5.50 \text { flowers per } \\
\text { for the number of flowers per cluster. } & \text { cluster (Table 2). while Minimum flower per } \\
\text { Statistically at per result was recorded in } & \text { cluster } 3.53 \text { were recorded in LINE-114, }\end{array}$} \\
\hline
\end{tabular}


significantly followed by LINE-112 3.66 flowers per cluster.

Researchers observed [18] similar results for flower per cluster. Experiment on 11 tomato cultivars was performed to evaluate the comparative performance at Northern Areas of Pakistan during 2003 and corroborating results were obtained for flower per cluster, while these differences among tomato lines are attributed to environment and temperature $[4,19]$.

\section{Fruits cluster-1}

Analyzed data showed significant difference between the lines for the parameter. The data showed highest number of fruits per cluster (4.88) in LINE-105, significantly followed by LINE-103 with 4.66 fruits per cluster and the lines were statistically at par with each other (Table 2). LINE-114 produced only 1.77 fruits per cluster significantly followed by LINE-112 with 2.10 fruits per cluster.

As the line 105 had more number of flowers per cluster, therefore it had more fruit per plants. The corroborating results of significant variation were also finds by [19] and [18]. for no of fruit/cluster under

Table 2. Data on fourteen lines for flower per cluster, fruit per cluster and per plant

\begin{tabular}{|c|c|c|c|}
\hline Tomato lines & Flower per cluster & Fruit per cluster & Fruit per plant \\
\hline LINE 101 & $5.68 \mathrm{bc}$ & $4.05 \mathrm{ab}$ & $23.66 \mathrm{c}$ \\
\hline LINE 102 & $6.50 \mathrm{ab}$ & $4.38 \mathrm{a}$ & $27.40 \mathrm{~b}$ \\
\hline LINE 103 & $5.74 \mathrm{bc}$ & $4.66 \mathrm{a}$ & $30.86 \mathrm{a}$ \\
\hline LINE 104 & $5.53 \mathrm{~b}-\mathrm{d}$ & $3.22 \mathrm{bc}$ & $21.55 \mathrm{~cd}$ \\
\hline LINE 105 & $6.67 \mathrm{a}$ & $4.88 \mathrm{a}$ & $32.00 \mathrm{a}$ \\
\hline LINE 106 & $4.61 \mathrm{de}$ & $3.08 \mathrm{c}$ & $20.73 \mathrm{c}-\mathrm{e}$ \\
\hline LINE 107 & $5.44 \mathrm{~cd}$ & $3.1 \mathrm{bc}$ & $20.62 \mathrm{c}-\mathrm{e}$ \\
\hline LINE 108 & $4.10 \mathrm{ef}$ & $2.88 \mathrm{~cd}$ & $18.29 \mathrm{ef}$ \\
\hline LINE 109 & $4.33 \mathrm{ef}$ & $2.99 \mathrm{~cd}$ & $20.33 \mathrm{de}$ \\
\hline LINE 110 & $3.77 \mathrm{ef}$ & $2.50 \mathrm{c}-\mathrm{e}$ & $16.77 \mathrm{fg}$ \\
\hline LINE 111 & $3.83 \mathrm{ef}$ & $2.72 \mathrm{~cd}$ & $16.99 \mathrm{f}$ \\
\hline LINE 112 & $3.66 \mathrm{ef}$ & $2.10 \mathrm{de}$ & $13.51 \mathrm{~h}$ \\
\hline LINE 113 & 3.77 ef & $2.33 \mathrm{c} / \mathrm{e}$ & $13.84 \mathrm{gh}$ \\
\hline LINE 114 & $3.53 \mathrm{f}$ & $1.77 \mathrm{e}$ & $9.62 \mathrm{i}$ \\
\hline LSD $\mathbf{5 \%}$ \%) & $\mathbf{0 . 9 5 9 4}$ & $\mathbf{0 . 9 2 5 3}$ & $\mathbf{3 . 1 4 6 0}$ \\
\hline
\end{tabular}

Means followed by different letters show significant result at $5 \%$ level of probability different locations. These differences among tomato lines might be due to environment and temperature prevailed at the experimental area.

\section{Fruits plant ${ }^{-1}$ :}

Significant difference was observed among all the lines for the parameter. It can be inferred from the data that number of fruits per plant were significantly affected in different tomato lines. The data showed that maximum fruits per plant were recorded in LINE-105 32.00 fruits per plant followed by significantly LINE-103 30.86 fruit per plant. While Minimum fruits per plant (9.62) were recorded in LINE-114, followed by significantly LINE-112 with 13.51 fruits per plant.

Experimentation on different tomato genotypes, at Kahriz station was conducted during two seasons in 2010-2011 and observed significant variation for fruit per plant. The differences may be attributed by differences in the genotypes, plant type, genetic potential of the genotypes and the environmental conditions of the testing environment [20]. 


\section{Fruit Diameter (cm)}

Statistical analysis showed significant variation for fruit diameter. Highly significant data regarding fruit diameter revealed that tomato LINE-105 produced maximum fruit diameter $(5.83 \mathrm{~cm})$ very closely followed by LINE-103 with $5.60 \mathrm{~cm}$ fruit diameter respectively and all these lines were statistically at par with each other, as shown in Table 3. Least response was observed in LINE-114 $(4.09 \mathrm{~cm})$ and LINE$112(4.26 \mathrm{~cm})$.

The variations among the genotypes for fruit diameter may be due to the differences in the genetic makeup of the genotypes and the environment where experiment was planned because different genotypes perform differently [21].

\section{Fruit Weight (gm)}

Fruit weight data showed significant difference among all the lines. Highly significant data depicted that significantly maximum fruit weight were found in LINE112 and LINE-114 with 105.10, $95.50 \mathrm{~g}$ respectively and all these lines were statistically at par to each other, as given in Table 3. The LINE-101 showed minimum fruit weight $(45.90 \mathrm{~g})$ significantly followed by LINE-103 with $59.43 \mathrm{~g}$ fruit weight respectively.

As the LINE-112 had lowest number of fruits per plant (Table 2), therefore it had utilized the food reserves for enhancing fruit size which resulted in increased fruit weight. Earlier researchers [17] also supported the similar findings of significant variation.

\section{Fruit Length (cm)}

Analysis of differences was shown significant variation for fruit length among all tomatoes lines. The analyzed data regarding fruit length showed significantly different behavior for different tomato lines. Maximum fruit length $(6.26 \mathrm{~cm})$ was observed in LINE-112 significantly followed by LINE-114 (6.20), respectively. LINE-101 got minimum fruit length
$(4.40 \mathrm{~cm})$ and was significantly followed by LINE-103 $(4.63 \mathrm{~cm})$.

Data in Table no 3 showed that LINE-112 had lowest number of fruit. It can be concluded that the LINE-112 might have minimum food reserves for increased fruit size. Significant differences for fruit length were also supported by Islam et al. (2011) studied nineteen segregate lines of tomato at the BARI Horticulture Research Centre during winter season of 2008-2009. Fifteen new cross of tomato genotypes were investigated at Horticultural Research Institute NARC, Islamabad, Pakistan in spring 2011 and similar results for fruit length were concluded. These differences among the genotypes for this character may be attributed to the differences in the genetic makeup of the genotypes and the testing environment of the study [18].

\section{Yield per Plant (g)}

The data shown in Table 4, revealed highly significant results for yield per plant (g) amongst the different tomato lines. LINE105 showed maximum yield per plant (1247.60 g) very closely followed by LINE$103(1220.80 \mathrm{~g})$ per plant respectively. LINE-112 showed minimum yield per plant $(397.90 \mathrm{~g})$ that was significantly followed by LINE-114 scoring $443.80 \mathrm{~g}$ tomato fruit yield per plant. Once again, tomato LINE101 and LINE-103, showed better performance in fruit yield per plant as they got maximum food assimilation, fruit length and average fruit weight, as compared to the other lines. This also shows that these lines are much more suitable to the local environmental, as they are showing consistence performance regarding better tomato yields.

Differences in the genotypes, genetic potential of the genotypes and the environmental conditions of the testing environment may the possible cause for these differences [21]. 
Table 3. Data on fourteen lines fruit diameter, fruit weight and fruit length

\begin{tabular}{|c|c|c|c|}
\hline Tomato Lines & Fruit Diameter (cm) & Fruit Weight (gm) & Fruit Length (cm) \\
\hline LINE 101 & $5.60 \mathrm{a}-\mathrm{c}$ & $45.90 \mathrm{i}$ & $4.40 \mathrm{f}$ \\
\hline LINE 102 & $5.60 \mathrm{a}-\mathrm{c}$ & $93.83 \mathrm{~b}$ & $5.95 \mathrm{ab}$ \\
\hline LINE 103 & $5.66 \mathrm{ab}$ & $59.43 \mathrm{~h}$ & $4.63 \mathrm{ef}$ \\
\hline LINE 104 & $5.53 \mathrm{a}-\mathrm{c}$ & $83.77 \mathrm{~cd}$ & $5.70 \mathrm{bc}$ \\
\hline LINE 105 & $5.83 \mathrm{a}$ & $88.33 \mathrm{bc}$ & $5.80 \mathrm{bc}$ \\
\hline LINE 106 & $5.43 \mathrm{bc}$ & $74.03 \mathrm{ef}$ & $5.53 \mathrm{~cd}$ \\
\hline LINE 107 & $5.49 \mathrm{a}-\mathrm{c}$ & $79.10 \mathrm{de}$ & $5.60 \mathrm{~b}-\mathrm{d}$ \\
\hline LINE 108 & $5.00 \mathrm{de}$ & $68.10 \mathrm{fg}$ & $5.30 \mathrm{~d}$ \\
\hline LINE 109 & $5.26 \mathrm{~cd}$ & $68.57 \mathrm{fg}$ & $5.46 \mathrm{~cd}$ \\
\hline LINE 110 & $4.82 \mathrm{e}$ & $65.67 \mathrm{gh}$ & $5.26 \mathrm{~d}$ \\
\hline LINE 111 & $4.86 \mathrm{e}$ & $65.00 \mathrm{gh}$ & $4.83 \mathrm{e}$ \\
\hline LINE 112 & $4.26 \mathrm{f}$ & $105.10 \mathrm{a}$ & $6.26 \mathrm{a}$ \\
\hline LINE 113 & $4.30 \mathrm{f}$ & $60.63 \mathrm{gh}$ & $4.67 \mathrm{e}$ \\
\hline LINE 114 & $4.09 \mathrm{f}$ & $95.50 \mathrm{~b}$ & $6.20 \mathrm{a}$ \\
\hline LSD $(\mathbf{5} \%)$ & $\mathbf{0 . 3 4 6 5}$ & $\mathbf{7 . 9 5 0 9}$ & $\mathbf{0 . 3 5 7 0}$ \\
\hline
\end{tabular}

Means followed by different letters show significant result at $5 \%$ level of probability

Table 4. Data on fourteen lines for yield per plant, pericarp thickness and shelf life

\begin{tabular}{|c|c|c|c|}
\hline Tomato lines & Yield per plant $\mathbf{( k g )}$ & Pericarp thickness $\mathbf{( c m})$ & Shelf life days \\
\hline LINE 101 & $1013.80 \mathrm{bc}$ & $0.72 \mathrm{bc}$ & $9.00 \mathrm{bc}$ \\
\hline LINE 102 & $1132.80 \mathrm{ab}$ & $0.72 \mathrm{bc}$ & $10.33 \mathrm{ab}$ \\
\hline LINE 103 & $1220.80 \mathrm{a}$ & $0.75 \mathrm{~b}$ & $11.33 \mathrm{a}$ \\
\hline LINE 104 & $989.90 \mathrm{c}$ & $0.68 \mathrm{~cd}$ & $8.66 \mathrm{~b}-\mathrm{d}$ \\
\hline LINE 105 & $1247.60 \mathrm{a}$ & $0.94 \mathrm{a}$ & $11.33 \mathrm{a}$ \\
\hline LINE 106 & $954.10 \mathrm{~cd}$ & $0.67 \mathrm{c}-\mathrm{e}$ & $8.66 \mathrm{~b}-\mathrm{d}$ \\
\hline LINE 107 & $959.40 \mathrm{~cd}$ & $0.68 \mathrm{c}-\mathrm{e}$ & $8.66 \mathrm{~b}-\mathrm{d}$ \\
\hline LINE 108 & $808.60 \mathrm{e}$ & $0.63 \mathrm{ef}$ & $7.66 \mathrm{~cd}$ \\
\hline LINE 109 & $858.80 \mathrm{de}$ & $0.63 \mathrm{~d}-\mathrm{f}$ & $7.00 \mathrm{~cd}$ \\
\hline LINE 110 & $548.40 \mathrm{f}$ & $0.61 \mathrm{f}$ & $7.33 \mathrm{c}-\mathrm{e}$ \\
\hline LINE 111 & $759.20 \mathrm{e}$ & $0.62 \mathrm{ef}$ & $4.55 \mathrm{f}$ \\
\hline LINE 112 & $397.90 \mathrm{~g}$ & $0.52 \mathrm{~h}$ & $5.66 \mathrm{ef}$ \\
\hline LINE 113 & $546.60 \mathrm{f}$ & $0.58 \mathrm{fg}$ & $5.00 \mathrm{f}$ \\
\hline LINE 114 & $443.80 \mathrm{fg}$ & $0.54 \mathrm{gh}$ & $\mathbf{1 . 6 9 0 6}$ \\
\hline LSD $\mathbf{5} \%)$ & $\mathbf{1 2 8 . 7 7}$ & $\mathbf{0 . 0 5 4 7}$ & \\
\hline
\end{tabular}

Means followed by different letters show significant result at $5 \%$ level of probability

\section{Pericarp thickness}

Significant difference was observed for pericarp thickness among all the lines. The data revealed that maximum pericarp thickness was recorded in LINE-105 (0.94 $\mathrm{mm})$.significantly followed by LINE-103 with $0.75 \mathrm{~mm}$ (table 4), respectively. While the LINE-112 had minimum pericarp thickness $0.52 \mathrm{~mm}$ that was significantly followed by LINE-114 with $0.54 \mathrm{~mm}$ pericarp thickness respectively. 
Maximum pericarp thickness $(0.94 \mathrm{~mm})$ was observed in Table 4. Therefore it can be concluded that LINE-112 minimum moisture loss which in increased shelf life. The present finding for pericarp thickness were supported by [22] who investigated various genotypes of tomato at Southwestern Romania. Thirty six tomato genotypes were studied and similar values for pericarp thickness 0.38 to 0.84 were observed [14].These may be due the differences in the genetic makeup, genetic potential of the genotypes and the environment study area.

\section{Shelf-life (days)}

Analyzed data of variances showed significant difference for shelf-life. The LINE-105 taken maximum days to shelf-life (11.33 days) closely followed by LINE-103, (10.33 days) respectively and all these lines were statistically at par with each other, as shown in Table 4 . While the minimum days for shelf-life were found in LINE-112 (4.55 days) significantly followed by LINE-114 (5.00 days). Different tomato genotypes were studied and obtained similar results for shelf life [23].

\section{Conclusion}

The LINE-105 was superior in terms of higher yield, flowers cluster ${ }^{-1}$, fruit plant $^{-1}$ and hence recommended for general cultivation. However the lines L108 and L109 showed better performance for various traits, except yield, and could be used in further breeding programs.

\section{Authors' contributions}

Conceived and designed the experiments: I Khan, I Hussain \& M Ahmed, Performed the experiments: I Khan \& M, Analyzed the data: SM Khan, A Khan \& K Naveed, Contributed reagents/ materials/ analysis tools: S Ali, I Hussain \& M Sajid, Wrote the paper: I Khan \& I Hussain

\section{References}

1. Free JB (1963). The flower constancy of honeybees. J Animl Eco 32: 119-131.
2. Dhaliwal MS, Singh S \& Cheema DS (2003). Line $\times$ tester analysis for yield and processing attributes in tomato. $J$ Res 40: 49-53.

3. Anonymous (2011). Agricultural statistics of Pakistan. Government of Pakistan. Ministry of Food, Agriculture and Livestock. Islamabad.

4. Zahedi MS \& Ansari NA (2012). Comparison in Quantity Characters (Flowering and fruit set) of ten selected tomato (Solanum lycopersicum L.) Genotypes under subtropical climate conditions (Ahvaz). Interl Res J App \& Bas Sci 3(6): 1192-1197.

5. FAOSTAT (2011). Production, Crops. Food and Agriculture Organization of the United Nations, Statistics Division, Rome, Italy. http://faostat3.fao.org/browse/Q/QC/E.

6. Osei MK, Bonsu KO, A Agyeman \& HS Choi (2014). Genetic diversity of tomato germplasm in Ghana using morphological characters. Internat. $J$ Plant Soil Sci 3(3): 220-231.

7. Whitney EN \& Rofles SR (2002). Understanding Nutrition. 9 ed: Thomas Learning, Inc.

8. Afroz A, Chaudry Z, Rashid U, Khan MR \& Ghulam MA (2010). Enhanced regeneration in explants of tomato (Lycopersicon esculentum L.) with the treatment of coconut water. Afr $J$ Biotech 24: 3634-3644.

9. Ishag S, Osman MG \& Khalafalla MM (2009). Effects of growth regulators and genotype on shoot regeneration in tomato (Lycopresicon esculentum C.V. Omdurman). Int J Sustain Crop Prod 6: 7-13.

10. Jilani MS, Waseem K, Ameer K, Jilani TA, Kiran M, Alizia AH \& Parveen A (2013). Evaluation of elite tomato cultivars under agroclimatic conditions of Dera Ismail Khan. Pak. J Agri Sci 50: $17-21$. 
11. Steel RGD \& Torrie JS (1980). Principal and procedure of statistics. McGraw Hill Book Company Inc., New York.

12. Haque MM, Rehman AKM \& Hossain SMM (1998). Physiological and yield potential of some promising tomato lines at different planting times. Pak $J$ Agric Res 9(3): 359-362.

13. Gongolee GAK, Osei MK, Akromah R, Nyadanu D \& Aboagye LM (2015). Evaluation of Some Introduced tomato cultivars. Horiz J Agric Food Sci 1(1): 001-006.

14. Chernet S, Belew D \& Abay F (2014). Performance evaluation and Path Analysis Studies in Tomato (Solanum lycopersicon L.) genotypes under Humera, Northern Ethiopia Condition. World J of Agricultural Res 2(6): 267271.

15. Naz, F, Haq IU, Asghar S, Shah AS \& Rahman A (2011). Studies on growth, yield and nutritional composition of different tomato cultivars in battal valley of district Mansehra, Khyber Pakhtunkhwa, Pakistan. Sarhad J Agric 27 (4): 569-571.

16. Ahmad F, Khan O, Sarwar S, Hussain A \& Ahmad S (2007). Performance evaluation of tomato cultivars at high altitude. Sarhad J Agric 23(3): 581-585.

17. Shah AH, S-ul- Munir, N-ul-amin \& Shah SH (2011). Evaluation of two nutrient solutions for growing tomatoes in a non-circulating hydroponics system. Sarhad J Agric 27(4).
18. Ramzan A, Khan TN, Nawab NN, Hina A, Noor T \& Jillani G (2014). Estimation of genetic components in F1 hybrid and their parents in determinate tomato (solanum lycopersicum $l.) . J$ Agric Res 52(1): 65-75.

19. Regassa MD, Mohammad A \& Bantte K (2012). Evaluation of tomato (lycopersicon esculentum Mill) genotype for yield and yield components. The Afri J Plnt Sci Biotech 6(1): 45-49.

20. Emami A \& Eivazi AR (2013). Evaluation of genetic variations of tomato genotypes (Solanum lycopersicum L.) with multivariate analysis. Inter J Sci Res Env Sci 1(10): 273-284.

21. MehrajH, Mutahera S, Roni MZK, Nahiyan ASM \& Jamal Uddin AFM (2014). Performance assessment of twenty tomato cultivar for summer cultivation in Bangladesh. J Sci Tech Env Info 1(01): 45-53.

22. Dar RA, Sharma JP, Nabi A \& Chopra S (2012). Germplasm evaluation for yield and fruit quality traits in tomato (Solanum Lycopersicon L.). Afr J Agric Res 7(46): 6143-6149.

23. Salas FM, Rosario AS, Vivian NP \& Marcelo AQ (2015). Shelf-life and free radical scavenging activity of tomato (Lycopersicon esculentum Mill.) fruits coated with safe phytochemicals. $J$ Food \& Nutr Sci 3(1-2): 94-99. 